RAINBOW Vol. 8(1)(2019)
UNNES Journal of Literature, Linguistics and Cultural Studies
http://journal.unnes.ac.id/sju/index.php/rainbow

\title{
Human Corruption as The Effect of Modern Technology as Represented in Okky Madasari's The Last Crowd
}

Hana Septiana Johariani ${ }^{\bowtie}$, Fatma Hetami

English Department, Languages and Arts Faculty, Universitas Negeri Semarang, Indonesia

\begin{tabular}{|c|c|}
\hline Article Info & Abstract \\
\hline $\begin{array}{l}\text { Article History: } \\
\text { Received } 29 \text { January } 2019 \\
\text { Approved } 25 \text { July } 2019 \\
\text { Published } 29 \text { July } 2019\end{array}$ & $\begin{array}{l}\text { Modern technology plays big roles in influencing human life, especially millenial } \\
\text { generation. However, it can create human corruption due to its function abuse. The } \\
\text { objectives of this study are: 1) to explain how human corruption is described in Okky } \\
\text { Madasari's The Last Crowd and 2) to explain how the modern technology creates human } \\
\text { corruption as described in Okky Madasari's The Last Crowd. The methodology used in } \\
\text { this study was descriptive-qualitative. This study analyzed the novel using Levi Strauss' } \\
\text { theory. There were two objects of the study, namely material object which was The Last } \\
\text { Crowd novel and formal object from the analysis of the novel using Levi Strauss' theory. } \\
\text { The results of the study are as follows: 1) Human Corruption was described in Okky } \\
\text { Madasari's The Last Crowd through how the characters in the novel use modern } \\
\text { technology unwise until it has a bad effect. Human corruption is divided into three kinds } \\
\text { of corruption; corruption in time, corruption in function and corruption in behavior. 2) } \\
\text { Human Corruption is created due to the influence of technology towards Jayanegara, } \\
\text { which triggers him to be trapped in it. It shows when he decides to make a pseudo-identity } \\
\text { for being a winner and a revenger. }\end{array}$ \\
\hline
\end{tabular}

(C) 2019 Universitas Negeri Semarang

\footnotetext{
Corresponding Author

E-mail: hanasepttiana@gmail.com
}

ISSN : 22526323 


\section{INTRODUCTION}

Modernization refers to a model of progressive transition from a "pre-modern" or traditional to a modern society (Ola, 2015:68). In other words, among life most conspicuous theories of social change and those that go under the name of "modernity" or "modernization" and include other related terms, such as "development" as well. (Haferkamp and Smelser, 1992:12). It is assumed that modernization can be defined as a process of transformation or a change in a more advanced or increasing direction in various aspects of society's life. When the modernization changes the present conditions of society, it affects all aspects and determines of socio-cultural indicators of development (Adnan and Bhatti, 2011:271). Modernization is something that cannot be separated from globalization. It is called as a change in attitude from someone to his/her life, someone who is not familiar with globalization will be different from someone who is familiar with globalization. Someone will become more sensitive or complicated about something because it is affected by globalization. Moreover, if someone cannot respond to the existence of globalization.

Modern technology is as one of modernization's tool, plays an important role in the era of modernization now, where technology has become an integral part of human life everyday. Since the internet and modern technology, with more accessible information, have drastically affected everyday life (Mihajlovic and Krzelj, 2014:15). it is assumed that modern technology encourages people to create a tool that works automatically to help, facilitate and accelerate human in working and completing the work with the best results. Beside the positive one, the increasing frequency of technological advances, it has a negative impacts on society. It is because the society are less in utilizing technological advance in this era of modernization. Many people are more interactive with their gadgets that in surroundings. The level of public awareness of the surrounding is diminishing, because they pay more attention to their gadgets. Modern technological developments can be an excuse for existing the decreasing in quality on society. The researcher takes one example of social change, it is corruption. Corruption (Oxford Living Dictionaries) denotes that the action of effect of making someone or something morally depraved. It can be said that corruption is a bad action which can effects the changes to people physically or mentally. In other words, corruption also can be said as decreasing, because corruption is decrease the function of something or do something that is not in accordance with the rules applied.

This condition is in line with the story in The Last Crowd, the novel written by Okky Madasari in 2016. It tells about a story of human confusion in the midst of a fast-changing digital era, when humans don't have much chance to stop, look back, and contemplate. Moving from one crowd to another, from connecting to alienating, we flock to the future and leave the past behind. Technology is a tool that makes everybody are busy to look for their crowds. Technology has transformed human civilization. Social network is the new world, where tremendous amount of time is spent running away from the harsh reality of the life filled with defeat and absurdity. Through the main character of the novel, he encounters problems and undesirable feelings which are indirectly linked to each other. The novel fells above the moral decadence of society towards the influences of modern technology. Human corruption created by the role of modern technology abused until change the function of modern technology to the bad things and damage.

Therefore, the researcher conducts a study to explain how the human corruption is described through the intrinsic elements and explain how the modern technology creates human corruption in the novel by analyzing the novel using LeviStrauss' theory of structuralism.

\section{METHODS}

This research uses qualitative research design since the findings constitute description in terms of words, phrases, sentences, and 
utterances, not numbers or graphics. The approach used is sociology of literature because the analysis covers the society and its life. In addition, the researcher uses theory of structuralism which focuses on how human corruption is described through its intrinsic elements and how human corruption is described as the effect of modern technology found in the novel by analyzing good and bad sides of the effect modern technology to main character and then dividing the levels of human corruption occurred by pseudo identity of the main character until how modern technology damaged him.

There are two types of data used; Primary data of this study are taken from The Last Crowd by Okky Madasari. The writer takes secondary data of this study from books, dictionaries, journals, essays, and articles.

The procedure of data collection includes reading the novel and some relevant references. Then the researcher identifies the contents of the novel and other references which are related to the topic of the research by underlining and numbering. After that, the data are interpreted to answer the problem of the research. The last step is inventorying the data interpretation in the observation sheet which consists of number of data, citation, data location, the interpretation, and answer of the research problems.

\section{RESULTS AND DISCUSSIONS}

\section{Human corruption is described in Madasari's The Last Crowd}

Human corruption is an action that is detrimental to oneself and others because the action is carried out not in accordance with its portion to get a certain goal. The human corruption created in this section is caused by bad experiences, then triggers the characters to do things that harm themselves. Human corruption is a phenomenon that often occurs around us nowadays, but it is precisely this problem that is often ignored by most people, even taking it lightly. Human corruption is described through the characters, how the characters use modern technology unwise. It is also described as corruption in time, in function, and in behavior.

\section{Corruption in Time}

In general, modern technology is a tool that makes it easier for users to communicate. However, now modern technology is not only for communication but also for taking pictures and videos, surfing using the internet, can be used to play games, etc. Of course, the many facilities available in modern technology are addictive to its users. Especially for users who are not wise in utilizing these facilities, it brings bad effects.

\section{Jayanegara}

Starting from the character of Jayanegara, Jayanegara is a new age man who is so enthusiastic about the development of modern technology. Modern technology has succeeded in making him a man of curiosity in every detail of the modern technology. Modern technology used by Jayanegara is HP and laptops, both of which are able to make Jayanegara gives up all his time to tamper with the two technologies.

(1)"I got a mobile phone six months after Father got his. Like a child with a new toy, I played with it all day long" (Madasari, 2016: 28).

Based on the quotation above, it can be described that Jayanegara corrupts at his time. He chooses to spend all his time playing cell phones. Of course, there are many obligations that he left because he was busy playing the new handphone.

Corruption in time is one of human corruption as the effect of modern technology. A person who does not use the cell phone until he spends or corrupts his time. It is surely detrimental to itself, a lot of time is wasted because playing mobile is too long.

\section{Sukendar}

(2)"When I lived there, Father bought me a television and a radio. Those two things were my companion during those firs weeks that I lived in Simbah's house" (Madasari, 2016: 23).

Based on the statement above, describing that modernity always exists in Sukendar. It can 
be seen in the way Sukendar familiarizes Jayanegara with modern objects such as television and radio. Sukendar wants Jayanegara like his father, that life must go forward, including being used to modern life.

That did not happen only in the Simbah house, but also in Sukendar's house. There are many modern technologies in place so that people at home are accustomed to the sophistication of modern technology.

(3)"If before he was frequently obliged to receive telephone cells while face to face with Mother, now he could contact whoever he wanted whenever he wanted without anyone knowing. Father got this new device not long after Mother had cut the cable of the telephone in our home" (Madasari, 2016: 28).

From the statement above, describes that Sukendar already has a variety of modern technological tools such as land lines and cell phones. It can also be described that Sukendar is not wise in using his modern technology. He had hurt his wife using his landline and cellphone, after that, he did not feel guilty instead of replacing more sophisticated modern technology in order to continue his negative action.

(4)"But over time Mother knew that Father could now be dishonest when the two of them were already in bed together. With this phone Father could keep sending messages without their being any sound at all" (Madasari, 2016: 28).

Quotation (4) portrays about how Sukendar corrupts his time to use the modern technology unwise. Sukendar spends his time while with his wife in bed to play cellphones with his affair.

\section{Maera}

(5)"I counted each second, waiting for Maera to put down her phone, hug me and lead me back to the bed. But she didn't do that either. She was just so engrossed in her world. Just as she had said before, now she could engross herself in her chats with Father" (Madasari, 2016: 197).

Maera is increasingly unable to control herself when she has to play cellphones when she has to do other work. For her, it used to be that playing cellphones is excessive is wasting time, talking to people she doesn't know through social media is not profitable, everything she must has a profit. However, now none of this applies to Maera.

Maera's human corruption is corruption in time, she spends his time looking at the cellphone screen for what she lingers there. The influence of modern technology is very large, all will be fine if the users are wise in its use. However, it will turn detrimental if the user is not wise.

\section{Corruption in Function}

The main function of mobile phones is as a means of communication via voice and short messages (SMS). Furthermore, the cellphone functions to capture radio broadcasts, television. In addition, it is also equipped with audio, camera, video, game and internet service functions. Meanwhile, the function of laptop is as a tool to solve work faster, increase the brain's creative power, is flexible, often used as a new field of money and as entertainment.

\section{Jayanegara}

Both of these modern technologies each have a good function for the community to complete all its affairs. However, in this sub chapter, is showed how modern technology can create human corruption. It is said corruption in function, where the function of modern technology is changed to be detrimental by its users.

(6)"I got a mobile phone six months after Father got his. Like a child with a new toy, I played with it all day long. One afternoon before Father came home, Mother asked me to teach her how to use it. I knew that Mother had asked me to teach her, not because she wanted one of her own. Mother undoubtedly wanted to 
be able to open Father's mobile phone. I taught her enthusiastically. This was the one way that I could avenge Mother's hurt without having to openly blame Father" (Madasari, 2016: 28).

In the quotation above, it can be shown that what used to be a cellphone function was one of them as a means of communication, Jayanegara turned it into a tool of revenge on his father. Jayanegara hated his father very much because Sukendar had hurt his mother's heart with the affair committed by Sukendar.

In addition, Jayanegara also changed the function of the mobile phone provided for things that are good at facilitating human activities, instead, he turned it into a tool that can be used easily to store pornographic images.

(7)"While my father was playing around with lots of women, I was still reasonably satisfied getting my pleasure from my own hand or occasionally from pictures of naked women which I downloaded from the Internet. These pictures I transferred to my mobile phone, so that I could open them whenever I needed them" (Madasari, 2016: 35).

In the statement above, it is more clear that Jayanegara is using a cellphone to store pornographic images. Over time, technology is increasingly sophisticated, so users must also be more sophisticated in using it. If all users are like Jayanegara, of course, each user will harm themselves.

Jayanegara corrupts in function of handphone, he changes the tool that should be to communication instead becomes his own satisfaction tool by storing pornographic images easily. Of course, it hurts himself. It causes addiction for him because he has consumed pornographic pictures that plunges him into a life that is not good any further.

In conclusion, it can be called corruption in function when the users changes the good function of modern technology becomes the bad one. For the bad function that is changed to harm others and themselves.

\section{Corruption in Behavior}

The existence of technology will be fine for the user if the user also uses it well. It will be inversely proportional, if the user is not wise in using. In this sub chapter, the researcher tells about how modern technology is able to influence and changes habits for users who are not wise through the characters in the novel.

Corruption in behavior is divided into four kinds of behavior's changes; being ignorance, being arrogant, being strange and being underhand.

\section{Being Ignorance}

Being ignorance is one of corruption in behavior as an effect of modern technology. The habit is formed due to excessive activity of modern technology so that it does not pay attention to the environment. Modern technology is a medium that is more than enough for users to play without regard to their environment.

\section{Maera}

Maera becomes someone who knows nothing about the environment. Maera lives with Jayanegara at his boarding house in Jakarta. Because there is modern technology and Maera is attracted to him, she increasingly does not care about Jayanegara.

(8)"I counted each second, waiting for Maera to put down her phone, hug me and lead me back to the bed. But she didn't do that either. She was just so engrossed in her world. Just as she had said before, now she could engross herself in her chats with Father" (Madasari, 2016: 197).

The quotation above describes that Maera is increasingly becoming someone who doesn't care about her environment. The world of technology is able to reverse its concern to turn into a gadget rather than its environment.

In conclusion, Maera is damaged in the behavior of modern technology by being someone who does not care about its surroundings because it is satisfied with modern technology facilities. The world of technology is 
able to give Maera a new world to pay more attention to it and live in it.

\section{Being Arrogant}

Changes in attitude caused by the existence of modern technology are being arrogant. It is corruption in behavior because of excessive interest in technology that changes Maera's attitude to arrogant. Arrogant is when Maera does not want to accept the advice of others and chooses to be clearly wrong. The most important thing for Maera is that she is on stage and her story is read by many people.

In conclusion, being arrogant from Maera arises because in the internet world she had just woken up, she feels that she had brought benefits to her. Maera feels appreciated when her writing was read by many people. Many people who give likes and comments, it is enough to make Maera happy because she feels it is not in vain to write it all down. Unlike when being a newspaper journalist, not many read it, not many also gives appreciation for Maera's work.

From the assumptions of success that she feels she had achieved, that caused her arrogant attitude. She does not need the opinions about her works, another person who does not agree with the steps she took to write like that. All she thinks of is all about recognition and victory in his new world. The point of corruption in behavior is when Maera changes her attitude to arrogant caused by her happiness in the new world.

\section{Being Strange}

Communicating through a cellphone screen really requires pretense. This was done by Jayanegara when communicating with his mother. It feels really different when I have to get used to communicating via SMS or telephone. There is a strange feeling that comes when they exchange messages.

(9)"One small instrument born out of modern technology created distance between me and Mother rather than bringing us closer. We felt more and more alienated from one another" (Madasari, 2016: 63).
Modern technology has a role to facilitate and also have limits in communication. The researcher concludes that it is communicated by telephone so that it has a limit to being strange and awkward in communicating.

\section{Being Underhand}

Another corruption in behavior is when Jayanegara is underhand because of modern technology. He corrupts the modern technology as a tool for searching the stage and acknowledging that he has not completely failed in his life. At first, this became a natural thing, but Jayanegara used other people to achieve this goal.

(10)"In the midst of this sea of voices, I had to find a way of getting my voice heard by Akardewa. I wanted to be seen and heard by Akardewa" (Madasari, 2016: 107).

Jayanegara's first way to enter the new world is to find people who are already famous there. Then Jayanegara enters the money room to get the attention of Akardewa and the Akardewa fans.

In conclusion, the researcher concludes that being underhanded is when Jayanegara is heard and seen because he is riding with Akardewa. He borrows the name Akardewa to become famous, after which Jayanegara walks on his own according to his story regardless of Akardewa as before.

\section{Human Corruption as the Effect of Modern Technology as Described in Okky Madasari's The Last Crowd}

In this subchapter, the researcher focuses on Jayanegara as playing the character, analyzing how Jayanegara is too far away in his new world. Various corruption that has been done by Jayanegara does not just stop, Jayanegara continues to achieve happiness that he has never achieved before.

\section{Pseudo-Identity on Jayanegara}

The new world gives new life to Jayanegara from its real life that is full of failures. Jayanegara can prove to be someone who is 
important and considered in the new world. Finally, Jayanegara decides to create a new identity as Matajaya. With hope, Matajaya can be a winner and can take revenge to Sukendar, unlike Jayanegara which is full of failures.

\section{Being a Winner}

Matajaya feels free because he can choose what part of happiness he wants to show or not, while Jayanegara feels restricted because he has to face what he does. The text of the novel that constructs the structure of pseudo-identity on Jayanegara: being a winner. To put it into a figure, the oppositions are as follows:

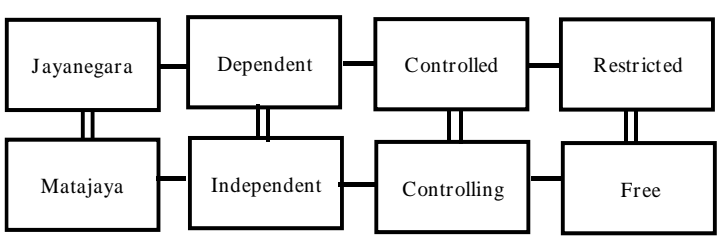

Figure 4.2.1.1. The Binary Oppositions of Pseudo-Identity on Jayanegara: Being a Winner

Being a Winner is a description of what he wants to achieve in his pseudo-identity which belongs to human corruption that Madasari describes in the novel. Madasari creates the condition of Jayanegara that changes the identity into Matajaya. Madasari describes that Jayanegara is dependent while Matajaya is independent, and that leads into the state that Jayanegara is being controlled while Matajaya is controlling. Jayanegara is restricted while Matajaya is free to do everything.

\section{Being a Revenger}

Matajaya gets his best position so that he can be considered a winner. Neither do you have a diploma like Jayanegara, but he is able to get a job that suits him. Of course, Matajaya is free from his father, able to meet his own needs and Mae without asking for a penny from his father. The text of the novel that constructs a structure of pseudo-identity on Jayanegara: Being a Revenger. To put it into a figure, the oppositions are as follows:

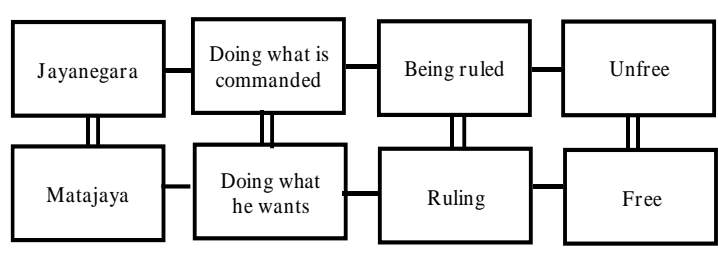

Figure 4.2.1.2. The Binary Oppositions of Pseudo-Identity on Jayanegara: Being a Revenger

Being Revenger is a description of the goals that he wants to achieve in his pseudo-identity which belongs to human corruption that Madasari describes in the novel. Madasari creates the condition of Jayanegara that changes the identity into Matajaya. Madasari describes that Jayanegara is doing what is commanded by the Father while Matajaya is doing what it wants to be a revenger, and that leads into that Jayanegara is being ruled while Matajaya is ruling. Jayanegara is unfree while Matajaya is free from his Father and all his commands.

\section{Jayanegara's Failure}

From the all binary oppositions that were explained, Jayanegara has the chance to get the victory he wanted by pretending to be Matajaya. His sense of revenge on his father continues to imagine him, feeling unsatisfied if Sukendar had not been destroyed like he had destroyed Mother. Then he did something worse with Kara.

Modern technology gives the convenience to find any information, its reach is broad and brings benefits to the users. Technology also easily provides great losses and dangers if not used wisely.

Everything starts by Jayanegara is pseudo, the success he got when he became Matajaya was also pseudo. Jayanegara, who wants to be separated from his father, actually needs his father to release him from prison because of a defamation case. Jayanegara just wants to hide from all the losses he got, he runs into a new world as a place to find a victory that makes him even more failed than before.

\section{CONCLUSION}

The conclusion of this research are, first conclusion is that human corruption as the effect of modern technology in Okky Madasari's The 
Last Crowd due to user discretion for using technology modern. Human corruption is explained through how the characters in the novel use modern technology unwise until it has a bad effect. All the characters are corrupt modern technology because modern technology has the charm of its own to cause addiction. Human corruption is divided into three kind of corruption; corruption in time, corruption in function and corruption in behavior. For the corruption in behavior, divided into four behaviors; being ignorance, being arrogant, being strange and being underhand.

The second conclusion is that to what extent modern technology can create human corruption in Okky Madasari's The Last Crowd. It focuses on the main character, Jayanegara. Jayanegara is the main character who continues his corruption in modern technology until he gets the goals that he wants. It explains more about pseudo-identity on Jayanegara that is divided into two goals; being a winner and being a revenger. Jayanegara changes his identity as Matajaya to become a winner and became an avenger to his father. He starts his new life with pseudo thing, he also gets pseudo results. The success in his new world through the internet is false and transient, in fact, the end result of his pseudo-identity is a failure that is more severe than before. In essence, human corruption gives the effect of corruption that the user does.

\section{REFERENCES}

Adnan, A. et al. (2011). International Journal of Business and Social Science. "Cognition and Impact of Modernization in Changing Normative Structure of Family System (A Case Study), pp. 271-277.

Haferkamp, H. and Nell J. Smelser (eds). (1992). Social Change and Modernity. Barkeley: The Regents of the University of California.

Ola, E. A. 2015. Journal of Humanities and Social Science. "Perspektives on The Impact of Modern Society on the Indigeneous Traditional Society of Nigeria." 4:67-74.

Madasari, Okky. (2016). The Last Crowd. Jakarta:Gramedia
Mihajlovic, I. and Zorica Krzelj. (2014). "'The Impact of Globalisation on The Development of Tourism Within Social and Economic Changes." European Scientific Journal. 8: 108120. 